\title{
HOW DO DISTURBANCE GENERATED PATTERNS INFLUENCE THE SPATIAL DYNAMICS OF ECOSYSTEM PROCESSES?
}

\author{
Monica G. TURner \ DEPARTMENT OF ZOOLOGY \ DEPARTMENT OF ZOOLOGY \\ UNIVERSITY OF WISCONSIN MADISON \\ WiLliam H. ROMME $\downarrow$ DEPARTMENT OF FOREST SCIENCES \\ COLORAdo STATE UNIVERSITY $\downarrow$ FORT COLLINS \\ DANIEL B. TINKER — DEPARTMENT OF BOTANY \ UNIVERSITY OF WYOMING \ LARAMIE
}

\section{$\checkmark$ BACKGROUND}

Our studies following the 1988 Yellowstone fires demonstrated that succession was surprisingly more variable in space and time than even current theory would have suggested, and that initial spatial patterns of disturbance may persist to produce longlasting changes in vegetation. Our focus now is on explaining the spatial and temporal patterns of succession and understanding how these patterns influence ecosystem function. The most interesting new questions revolve around the degree to which the spatial variation in postfire vegetation -- in particular, the six orders of magnitude variation in pine sapling density, ranging from 0 to greater than 500,000 saplings/ha --controls the spatial variability in ecosystem processes across the landscape. In our current research, we are conducting studies in both Grand Teton and Yellowstone National Parks to answer four major questions:

1. Does the spatial heterogeneity of processes such as ANPP, nitrogen mineralization, and decomposition change with time since fire? How quickly do spatial patterns in processes develop following a large fire?

2. How does the spatial pattern of coarse woody debris vary across the post-1988 landscape, and what is the importance of this variation for ecosystem function? Are patterns of coarse woody debris abundance related to both prefire stand structure and postfire sapling density?

3. Do the enormous differences in postfire tree density produce differences in carbon and nitrogen availability across the landscape? Or, is nutrient availability governed largely by broad-scale (i.e., $10 \mathrm{~s}$ of $\mathrm{km}$ ) abiotic gradients (e.g., climate, substrate) and/or fine-scale (i.e., less than $10 \mathrm{~cm}$ ) heterogeneity in resources or the microbial community, such that nutrient variability is not sensitive to the spatial variation in plant community structure?

4. Does the disturbance-created mosaic leave a persistent functional legacy? What mechanisms in vegetation development may contribute to convergence (or divergence) in 
ecosystem structure and function across the landscape as succession proceeds?

\section{$\downarrow \quad$ FINDINGS AND STATUS}

We completed our field sampling for questions 2 and 4 in 2004. In 2005 we conducted field work to address components of questions 1 and 3 in both Grand Teton / Rockefeller parkway and Yellowstone National Parks.

\section{Studies in Grand Teton National Park / Rockefeller Parkway}

Question 1: In 2003, we initiated a pilot fertilization study in the 2000 Glade Fire, in which replicate plants of several target species received a modest fertilizer amendment. Although nitrogen is considered to be limiting to vegetation growth throughout the subalpine forests of the Rocky Mountains, studies have not empirically demonstrated this limitation in early successional postfire forests.

Initial plant cover was measured before treatment in 2003, then again in 2004, at which time fertilizer treatments were once more applied. In 2005 we made final measurements of plant cover, and also harvested the plants (above and below-ground portions) to determine whether there has been a response to the treatment.

Laboratory work was completed in the winter of 2005-2006, to measure dry-weight biomass and foliar nitrogen content of all the plants harvested in 2005. Statistical analysis is now underway, with manuscript preparation planned for spring of 2007.

\section{Studies in Yellowstone National Park}

Question 3. Elizabeth Levitt, graduate student in ecology at the University of Wisconsin, completed her M.S. thesis in which she asked whether the differences in stand characteristics observed in 17-yr old post-fire lodgepole pine (Pinus contorta) were associated with differences in inorganic soil nitrogen availability. She sampled 25 stands that burned in the 1988 fires. Free resin bags were used as an index of nitrogen availability during the growing season, distributed randomly in each stand in June 2005 , retrieved in September 2005 and extracted for nitrate (NO3-) and ammonium (NH4+). Observed stand characteristics included vegetation, forest floor cover, litter quality and quantity and soils. Overall, vegetation explained 58\% and litter explained 19\% of the variability in soil $\mathrm{N}$ availability among 25 stands. Of these attributes, graminoid cover (grasses and sedges) explained $51 \%$, while pine sapling density explained $7 \%$ of the variation in the model. Litter quantity and quality explained $14 \%$ and $5 \%$ of the variation, respectively. Pine sapling density was negatively related to $\mathrm{N}$ availability $(\mathrm{R} 2=0.25$; $\mathrm{p}=0.01$ ). Within-stand heterogeneity of inorganic $\mathrm{N}$ availability as measured by coefficients of variation (CV) ranged from 47 to $284 \%$ among stands, and CVs were largely attributed to litter mass (partial $\mathrm{R} 2=0.47, \mathrm{p}<0.001)$. The results of this study showed that postfire differences in vegetation structure were associated with patterns of $\mathrm{N}$ availability almost 20 years after the 1988 fires in YNP.

Levitt also left resin bags in the same set of 25 stands for retrieval in 2006 , to compare patterns in mineralization during the course of a summer (2005) and a year (2005-2006).

\section{ACKNOWLEDGEMENT}

This research is supported by a grant from the Andrew W. Mellon Foundation. We greatly appreciated housing and logistical support provided by the UW-NPS Research Center at the AMK Ranch. 